\title{
DIPLOMASI SPIRITUAL KULTURAL DALAM PENCEGAHAN PEMBAYARAN DIYAT SEBAGAI UPAYA PERLINDUNGAN HUKUM WNI DI LUAR NEGERI YANG MENERAPKAN SYARIAT
}

\author{
Kholidah Tamami ${ }^{\bowtie}$ \\ Sekolah Tinggi Ilmu Fikih (STIF) Syeikh Nawawi Tanara Serang Banten - Indonesia
}

\begin{abstract}
Abstrak
Program perlindungan Warga Negara Indonesia (WNI) di luar negeri salah satu agenda program Nawacita pemerintahan presiden Joko Widodo-Jusuf Kalla. Beberapa upaya perlindungan di Timur Tengah, pemerintah sering terbentur dengan qishas yang merupakan bagian dari hukum Islam di negara tersebut. Vonis mati yang menimpa WNI terjadi karena keluarga korban tidak memaafkan WNI yang diduga bersalah, bahkan kuasa raja tidak dapat mengintervensi hal tersebut. Kehadiran negara dalam bentuk pemberian bantuan pengacara, pelibatan tokoh setempat merupakan jalan diplomasi yang dapat meringankan WNI yang terkena hukuman di negara tersebut. Sepanjang tahun 2015 Kementerian Luar Negeri melalui Perwakilan RI di beberapa negara telah berhasil membebaskan 48 WNI dari ancaman hukuman mati salah satu upaya dilakukan oleh KBRI/KJRI melalui pembayaran diyat. Penelitian ini menggunakan metode kualitatif yang bersifat deskriptif analisis dengan mengumpulkan data observasi, wawancara, pengumpulan dokumen serta rekaman.
\end{abstract}

Kata Kunci: hukum waris islam, kontemporer, hermeneutika 


\begin{abstract}
The program to protect Indonesian citizens (WNI) abroad is one of the agendas for the Nawacita program of the Joko Widodo-Jusuf Kalla administration. Some of the protection efforts in the Middle East, the government often collides with qishas which is part of Islamic law in the country. The death sentence that befell the Indonesian citizen occurred because the victim's family did not forgive the Indonesian citizen who was suspected of being guilty, even the power of the king could not intervene in this matter. The presence of the state in the form of providing assistance from lawyers, involving local figures is a way of diplomacy that can relieve Indonesian citizens who are sentenced to prison in that country. Throughout 2015, the Ministry of Foreign Affairs through Indonesian Representatives in several countries has succeeded in freeing 48 Indonesian citizens from the threat of the death penalty. This study uses a descriptive qualitative method of analysis by collecting observation data, interviews, document collection and recording.
\end{abstract}

Keywords: islamic inheritance law, contemporary, hermeneutics

Copyright (c) 2021 Kholidah Tamami.

$\triangle$ Corresponding author: Kholidah Tamami

Email Address : kholidah.tamami@syentra.ac.id

\title{
PENDAHULUAN
}

Nawacita atau 9 agenda pemerintah Jokowi-JK mencantumkan program pokok yang salah satunya adalah perlindungan warga Indonesia di luar negeri. Namun demikian, terdapat satu titik dimana pemerintah sama sekali tidak dapat melakukan upaya penyelamatan terhadap Warga Negara Indonesia (WNI). Titik itu berkenaan dengan qishas yang menimpa WNI yang telah ditetapkan sebagai tersangka pada tindak kejahatan di beberapa negara yang menerapkan hukum Islam. Kondisi yang terjadi adalah di saat keluarga korban tidak dapat memberikan maaf kepada WNI yang menjadi tersangka, maka vonis mati tidak dapat dihindari. Bahkan, raja tidak bisa mengintervensi, sehingga pemberian maaf dari keluarga korban dinilai sangat penting mengingat sistem hukum yang dianut di Arab Saudi. Sosiolog Universitas Sumatera Utara, Prof. Badaruddin menyarankan pemerintah melakukan pendekatan kepada keluarga korban pembunuhan. Hal ini dianggap lebih berhasil bila dibandingkan pendekatan diplomatik. ${ }^{1}$ Sebetulnya dalam era felksibilitas seperti sekarang ini, hal tersebut dapat dikategorikan sebagai diplomasi spiritual kultural.

Dalam upaya perlindungan WNI di negara yang menerapkan hukum qishas seperti Arab Saudi, pemeintah memiliki komitmen yang tinggi untuk melindungi WNI di luar negeri. Komitmen tersebut yaitu memastikan kehadiran negara dalam setiap kasus hukum dengan cara memberikan perlindungan kepada semua WNI. Termasuk yang sedang mengalami kasus hukum di luar negeri. Kehadiran negara diwujudkan dalam bentuk pemberian bantuan pengacara (lawyer) yang telah disiapkan KBRI atau KJRI melalui peninjauan ke penjara, menghadirkan keluarga untuk bertemu dengan WNI, pelaksanaan upaya diplomatik dan pelibatan tokoh setempat, seperti Dewan Pemaafan yang ada di Arab Saudi. Pemerintah menggunakan jasa 17 pengacara tetap di berbagai negara, guna melakukan upaya litigasi untuk memastikan hak-hak hukum WNI yang menghadapi permasalahan di luar negeri terpenuhi. Berkenaan dengan hal tersebut, sepanjang tahun 2015 Kementerian Luar Negeri melalui Perwakilan RI di beberapa negara telah berhasil membebaskan 48 WNI dari ancaman hukuman mati, 12

${ }^{1}$ Republika, 18 Juli 2011. 
di antaranya di Arab Saudi. ${ }^{2}$ Salah satu cara pembebasan para WNI yang terkena hukuman mati yaitu melalui pembayaran diyat.

Kasus diyat menjadi sebuah fenomena yang terjadi pada Tenaga Kerja Indonesia (TKI) di Timur Tengah, khususnya Arab Saudi. Maraknya kasus diyat yang terjadi disebabkan para TKI di Arab Saudi dianggap melakukan tindak kejahatan yang berat seperti pembunuhan. Sistem hukum di Arab Saudi yang notabene menggunakan syariat Islam menerapkan hukuman mati bagi pelaku pembunuhan. Arab Saudi sendiri merupakan negara paling banyak terdapat Tenaga Keja Indonesia (TKI), namun setelah moratorium tahun 2011 jumlah TKI ke Arab Saudi menurun. ${ }^{3}$ Menurut data Badan Nasional dan Perlindungan Tenaga Kerja Indonesia (BNP2TKI) mayoritas TKI adalah perempuan yang bekerja sebagai pekerja rumah tangga. ${ }^{4}$ Mereka inilah yang rentan mengalami kasus kriminal, terutama pembunuhan. Kebanyakan dalih TKI yang melakukan pembunuhan adalah upaya untuk membela diri akibat terjadi penyiksaan fisik atau kejahatan seksual oleh majikan. Akibatnya bagi yang tidak mendapat ampunan atau pemaafan dari keluarga korban, mereka mendapat vonis hukuman mati. Namun demikian, ada juga yang mendapat ampunan atau pemaafan dari keluarga korban dengan syarat pembayaran diyat.

Menurut data dari Konsulat Jendral RI untuk Jeddah, Pada tahun 2015 terdapat 14 warga negara Indonesia (WNI) terancam hukuman mati di Arab Saudi. Dari 14 kasus tersebut, 13 di antaranya berkaitan dengan pembunuhan sementara satu sisanya merupakan kejahatan zina muhsan atau hubungan zina antara pria dan wanita yang telah menikah. ${ }^{5}$ Sejumlah 14 WNI yang terancam hukuman mati tersebut, 2 WNI telah dieksekusi mati oleh pemerintah Arab Saudi, yaitu Siti Zaenab yang membunuh majikannya serta Karni yang membunuh anak berumur 4 tahun. Segala upaya telah dilakukan oleh Kemlu, mulai dari pendampingan hukum, menyediakan pengacara dan penerjemah hingga upaya diplomatik. Namun, keduanya tidak mendapatkan pemaafan dari keluarga korban. Selain itu, beberapa kasus WNI yang terbebas dari hukuman mati dengan pembayaran diyat oleh pemerintah, yaitu WNI bernama Darsem yang divonis mati karena membunuh anggota keluarga majikannya. Namun, setelah pemerintah membayar diyat sebesar 2 juta riyal atau 4,6 miliar rupiah, Darsem bebas dari hukum pancung dan bisa kembali ke tanah air. Kasus lainnya, yaitu kasus Satinah binti Jumadi Amad seorang WNI asal Ungaran, Kabupaten Semarang, Jawa Tengah. Pada 2011 Satinah divonis hukuman mati oleh Pengadilan Buraidah, Arab Saudi. Ia mengakui telah membunuh majikannya, Nurah binti Muhammad Al Gharib, 70 tahun dan mengambil uang milik korban sejumlah 37,970 riyal Arab Saudi atau sekitar 119 juta rupiah. Hukuman mati terhadap Satinah awalnya dilaksanakan pada Agustus 2011 kemudian diundur Desember 2011, Desember 2012, dan Juni 2013. Hukuman mati terhadap Satinah dihapus setelah pihak ahli waris keluarga korban memberi maaf dengan tuntutan uang diyat sebesar 7 juta riyal atau sekitar 21 miliar rupiah. Hal ini tidak terlepas dari pendekatan yang dilakukan oleh kemlu terhadap keluarga korban.

Selain beberapa WNI yang berhasil bebas dari hukuman mati melalui pembayaran diyat, terdapat juga beberapa WNI yang tidak bisa diselamatkan dari

\footnotetext{
2http:/ /internasional.metrotvnews.com/read/2015/11/09/189129/281-wni-terancamhukuman-mati-di-luar-negeri

3Palmira Permata Bachtiar, "Migration Outflow and Remittance Patterns in Indoensia: National as well as Subnational Perspectives". Philippine Journal of Development, Vol. 38, No. 1 \& 2 (2013): 32.

4BNP2TKI, Data Penempatan dan Perlindungan Tenaga Kerja Indonesia Tahun 2015 (Periode 1 Januari S.D 31 januari) Posisi Cetak Data Tanggal 12 Februari 2015, (Jakarta: 2015), hlm. 3 - 8.

5http://www.cnnindonesia.com/internasional/20150205160919-120-29941/belasan-wniterancam-hukuman-mati-di-arab-saudi/
} 
hukuman mati. Menurut data dari Migrant Care, Lembaga Swadaya Masyarakat yang peduli terhadap masalah TKI mengatakan selama 10 tahun pemerintahan Presiden Susilo Bambang Yudhoyono terdapat tiga TKI yang sudah dieksekusi mati di Arab Saudi, yaitu Yanti Iriayanti, Agus Damsiri dan Ruyati. ${ }^{6}$ Meskipun pemerintah sudah berupaya semaksimal mungkin, namun pihak keluarga korban tidak memberikan maaf.

Berkenaan dengan hal tersebut, pembayaran diyat yang dilakukan pemerintah dalam upaya perlindungan WNI menjadi perdebatan serius di tengah masyarakat. Ada yang beranggapan bahwa pemerintah wajib membayar diyat berapapun yang diminta keluarga korban sebagai wujud dari perlindungan WNI di luar negeri. Namun ada juga yang menganggap pembayaran diyat oleh pemerintah dianggap kurang tepat bila dijadikan sebagai solusi untuk melindungi WNI yang umumnya adalah para pekerja di sektor domestik (rumah tangga) di Arab Saudi.

Berdasarkan uraian di atas, kasus diyat yang menimpa WNI di Timur Tengah khususnya Arab Saudi terjadi pada WNI yang dianggap melakukan tindak kejahatan berat, seperti pembunuhan. Sistem hukum di Arab Saudi menerapkan hukuman mati bagi pelaku pembunuhan. Namun apabila keluarga korban memaafkan sang pelaku, maka hukuman mati itu tidak terjadi. Namun demikian, tersangka terkena kewajiban membayar diyat yang mengharuskan pelaku kejahatan membayar sejumlah uang yang telah ditetapkan keluarga korban sebagai ganti rugi atas kejahatan oleh pelaku kepada korban. ${ }^{7}$

Dalam upaya perlindungan WNI, pemerintah mengalami dilema dalam menangani WNI yang terkena kewajiban membayar diyat. Hal ini mengingat pembayaran diyat pada beberapa kasus dibebankan sepenuhnya pada pemerintah sebagai penanggung jawab otoritas negara. Di sisi lain, pembayaran diyat yang nilainya mencapai milyaran rupiah tersebut selain tidak masuk dalam APBN, juga dianggap sebagai beban negara. Hal ini disebabkan karena dana yang dikeluarkan pemerintah untuk pembayaran diyat tersebut lebih layak digunakan untuk kepentingan yang memberikan manfaat lebih besar bagi rakyat Indonesia. Oleh karena itu diperlukan jalan lain berupa diplomasi spiritual kultural yang dapat menghasilkan kata "maaf" sebagai jalan dibebaskannya hukuman.

\section{METODE PENELITIAN}

Penelitian ini menggunakan metode kualitatif yang bersifat deskriptif analisis dengan mengumpulkan data observasi, wawancara, pengumpulan dokumen serta rekanan, penulis melakukan pengumpulan data dengan cara menelusuri berbagai macam dokumen berupa buku, regulasi dan artikel pada website yang terkait seputar Asuransi Syariah. Hasil penelusuran ditulis dalam bentuk naratif. Studi dokumentasi yang dilakukan penulis seperti pendalaman untuk melakukan kajian dan interpretasi.

\section{HASIL DAN PEMBAHASAN}

Penelitian ini memberikan kontribusi pengetahuan yang bersifat empirik mengenai persepsi publik dalam melihat kasus diyat yang menimpa TKI di luar negeri yang notabene adalah WNI. Penelitian ini menggunakan metode kualitatif yang bersifat deskriptif analisis. Pendekatan kualitatif menurut Moleong adalah metode yang digunakan untuk memahami fenomena secara holistik yang dideskripsikan dalam

${ }^{6}$ http://news.okezone.com/read/2014/10/12/337/1051244/selama-sby-presiden-tigaburuh-migran-dihukum-mati

${ }^{7}$ Frank E. Vogel, Islamic Law and Legal System: Studies of Saudi Arabia, (Leiden: Brill, 2000), hlm. 224. 
bentuk kata-kata dan bahasa pada suatu konteks alamiah dengan memanfaatkan berbagai metode ilmiah. ${ }^{8}$ Menurut Mishler dalam Taskhakkori dan Teddlie metode kualitatif pada akhirnya bertujuan untuk mendeskripsikan dan menjelaskan pada tingkat tertentu adanya pola keterkaitan yang dapat dilakukan hanya dengan konsep kategori analitis khusus. ${ }^{9}$ Huberman dan Miles menyatakan bahwa pendekatan kualitatif berwujud kata-kata dan bukan rangkaian angka. ${ }^{10}$ Data dikumpulkan dalam berbagai cara di antaranya observasi, wawancara, dokumen serta rekaman. Selanjutnya, data tersebut diedit untuk dianalisis berdasarkan teori dan disusun dalam teks yang diperluas.

Pendekatan ini memetakan dan menganalisa pendapat para pemangku kepentingan, peran aktor pembentuk persepsi publik, serta kebijakan yang berlaku di beberapa negara lain terkait kasus diyat. Melalui pendekatan kualitatif ini, peneliti terjun langsung ke lapangan untuk melakukan wawancara dengan informan dari berbagai pemangku kepentingan yang mengerti dan mengamati kasus diyat di Arab Saudi.

\section{Diyat dan Implementasinya}

Arab Saudi merupakan negara Nomokrasi Islam yang berlaku sejak tahun 1950, dimana pemerintah Saudi menerapkan syariah sebagai landasan konstitusi negara. ${ }^{11}$ Syariah menjadi dasar hukum dalam penerapan legislasi (UU) dan jurisprudens (hukum) yang berlaku bagi tindak pidana maupun perdata di negara tersebut. Dalam pengambilan kebijakan, pemerintah Saudi menggunakan Al-Quran dan Hadist sebagai pijakan utama dan interpretasi yang digunakan adalah pendapat Mazhab Ibn Hanbal.

Awal berdiri negara Saudi, politik dan pemegang kebijakan mutlak diatur oleh keluarga kerajaan. Tetapi pada tahun 1953, dibentuk badan administrasi yakni Dewan Kementerian Saudi. Kemudian dilakukan reformasi politik di tahun 1993 yang membuka 3 perkembangan konstitusi di negara tersebut yakni: Pertama, dibentuknya formatur Consultative Council/Majelis Al-shura (Dewan Penasihat). Kedua, restrukturisasi pemerintah regional Kerajaan Arab Saudi. Ketiga, mengumumkan sistem dasar inkorporasi perkembangan satu dan dua. ${ }^{12}$

Otoritas pemerintah Arab Saudi terdiri dari otoritas Judisial, Eksekutif dan Regulator. Raja tidak memiliki otoritas mutlak dan tidak berdiri sendiri. Raja memiliki Dewan Penasihat (Majelis Al-Shura) dan Dewan Kementerian untuk mengambil regulasi kebijakan. Elit ulama memiliki pertimbangan untuk mempengaruhi kebijakan yang ada pada pemerintah Saudi dan memiliki hak istimewa sebagai dewan penasehat Raja. Majelis Al-shura dipilih empat tahun sekali berdasarkan kalender Hijriyah dan memiliki fungsi sebagai berikut:

1. Untuk mendiskusikan dan mengungkapkan pandangan kebijakan umum untuk perkembangan sosial dan ekonomi negara.

${ }^{8}$ J. Lexy Moelong, Metodelogi Penelitian Kualitatif. (Bandung: Remaja Rosdakarya, 2007), hlm.

6

9 Abbas Tashakkori dan Charles Teddlie, Mixed Methodology Mengombinasikan Pendekatan Kualitatif dan Kuantitatif. (Yogyakarta: Pustaka Pelajar, 2010), hlm 197.

${ }^{10}$ Michael Huberman dan Matthew B. Miles, Analisis Data Kualitatif: Buku Sumber Tentang Metode-Metode Baru. (Jakarta: UI Press, 2009), hln 15 - 16.

${ }^{11}$ Nomokrasi Islam adalah suatu negara hukum yang menggunakan prinsip-prinsip penting Islam seperti: kekuasaan sebagai amanah, musyawarah, keadilan, persamaan, kebebasan dan kesejahteraan, pengakuan dan perlindungan terhadap manusia, peradilan bebas, perdamaian, kesejahteraan rakyat. Majid Khadduri mendefinisikan Nomokrasi Islam yaitu suatu sistem pemerintahan yang didasarkan pada suatu kode hukum: rule of law dalam suatu masyarakat.

${ }^{12}$ Fouad Al-Farsy. Modernity and Tradition The Saudi Equation. (United Kingdom: Knight Communications, 2001). Hlm. 53. 
2. Untuk mempelajari dan menyarankan hal yang pantas bagi peraturan, regulasi, perjanjian dan MoU Internasional.

3. Untuk membahas dan menyarankan isi laporan tahunan kepada Kementerian dan Departemen negara.

Terdapat kurang lebih 7000 - 1000 ulama di Arab Saudi dengan komposisi hanya 25-30 ulama menjadi Dewan Penasihat. ${ }^{13}$ Kepemimpinan ulama sendiri ditunjuk oleh otoritas pengambil kebijakan, yakni sekitar 30-40 alim (ilmuwan) yang memiliki akses langsung kepada Raja. Sedangkan Dewan Konsultasi ditunjuk oleh Raja untuk memimpin institusi seperti Al-Majelis al-'ali li'l-Qada yakni Dewan Tertinggi Hakim; Dar al-ifta' wa'l Ishraf 'ala'l-Shu'un al-Diniyya yakni Dewan yang menangani ilmu pengetahuan dan permasalahan isu-isu agama; Hay'at al-Amr bi'l Ma'ruf wa al'Nahyi 'an al-Munkar yakni institusi yang menangani moral dan merupakan tentara keamanan.

Dewan Penasehat atau Majelis Al-syura bertanggungjawab terhadap resolusi draft yang akan disahkan oleh Kementerian dan Raja. Posisi ulama dalam sistem pemerintah Arab Saudi menunjukkan bahwa ulama memiliki otoritas penting terhadap regulasi dan konsiderasi untuk mempengaruhi kebijakan. Raja dapat mewakilkan kewenangan dalam implementasi fungsi judisial kepada para wakilnya. Sedangkan Majelis wakala atau Dewan Perwakilan bertugas secara langsung terhadap perkembangan infrastruktur maupun keamanan, keadilan maupun hak-hak warga negara dan kebebasan dalam framework syariah. ${ }^{14}$

Penerapan hukum dan sistem peradilan yang digunakan di Arab Saudi menggunakan syariah dimana kasus kriminalitas dan kasus-kasus yang melibatkan warga sipil diselesaikan dengan hukum tersebut, termasuk pada masalah diyat dan qishas. Meskipun Dektrit Raja adalah UU teratas dalam konstitusi Saudi, sebagai peradilan permohonan dan sumber pemaafan, namun pada tataran pemaafan bagi diyat dan qishas, raja tidak memiliki kekuatan dalam memutuskan. ${ }^{15}$

Sistem peradilan Saudi pada dasarnya terbagi ke dalam tiga katagori hirarki yakni: Pengadilan Ekspedisi, Pengadilan Syariah dan Komisi Pengawasan Judisial. Peradilan terbesar dipegang oleh pengadilan syariah yang menangani kasus-kasus yang banyak melanggar legal system seperti diyat dan qishas yang akan diproses melalui peradilan ini.

Konstitusi Arab Saudi memiliki kekhasan konstitusi yakni adanya Haqul 'Aam (hak raja) dan Haqul Khos (Hak keluarga korban). Dalam Basic Law Constitution disebutkan bahwa Raja memiliki konsiderasi hukum tertinggi yakni memiliki hak veto dalam resolusi dewan kementerian yakni otoritas judisial, eksekutif dan regulasi sesuai dengan fungsinya. Tetapi pada kasus tertentu seperti diyat dan qishas, hak mutlak ada pada Haqul Khos yakni keputusan ada pada ahlud dam (keluarga korban) dan siapapun tidak bisa melakukan intervensi.

Penjelasan mengenai keputusan diyat dan qishas dijelaskan oleh Muhammad Sadri dari Dit. PWNI \& BHI Kementerian Luar Negeri RI yakni kasus diyat merupakan persoalan yang masuk ke dalam ranah khos dimana pemerintah dalam hal ini raja tidak bisa mengintervensi keputusan keluarga korban. Bahkan keputusan keluarga dapat berubah sampai detik terakhir masa eksekusi. ${ }^{16}$ Dalam penyelesaian khusus kasus diyat

\footnotetext{
13http://www.mongabay.com/history/Saudi_Arabia/Saudi_arabia-the_ulama.html (diakses pada 19 Oktober 2015)

14 Dapat dibaca dalam The Basic Law of Government No:A/90 Chapter Six: The Authorities of The State artikel 44.

${ }^{15}$ https://www.saudiembassy.net/about/countryinformation/government/legal_and_jud icial_structr.aspx (diakses pada 23 November 2015)

16 Wawancara eksklusif Bpk. Muhammad Sadri, Perwakilan Perlindungan WNI (PWNI) Kementerian Luar Negeri RI pada tanggal 12 November 2015 pukul. 12.35 WIB
} 
dan qishas menurut Ahmad Masbukin, Diplomat RI untuk Riyadh, bahwa pemerintah Saudi membentuk badan mediasi yakni Lajnah Aflah Lil-islahil Bayin yakni badan yang bertugas untuk memediasi keluarga korban dan pelaku tindak pidana qishas. Biasanya dikepalai oleh Amir Mantiqoh, tokoh setempat yang memiliki wibawa dan kedudukan yang dihormati di masyarakat. ${ }^{17}$

Proses jatuhnya hukuman diyat sebelum masuk ke dalam peradilan tinggi syariah diselesaikan melalui proses diplomasi di Lajnah Aflah Lil-islahil Bayin. Pada mekanisme ini pemerintah yang diwakili oleh Kementerian Luar Negeri melakukan pendampingan dalam proses negosiasi dan pendekatan diplomatik maupun kultural kepada keluarga korban. Hal ini sebagai pendekatan dalam pemaafan bagi pelaku qishas dan jika dimaafkan maka negosiasi berlanjut pada kisaran pembayaran diyat.

Pada dasarnya tugas dari Lajnah Aflah lebih kepada memberi masukan kepada keluarga korban untuk berlaku bijak dalam pengambilan keputusan. Keputusan yang diambil tidak lepas dari pengaruh kepala suku dan masyarakat yang ada di suku tersebut. Hal ini disampaikan oleh Ahmad Masbukin selaku diplomat RI dalam pendampingan TKI yang terkena kasus diyat. Ia menjelaskan bahwa tradisi Arab Saudi tidak lepas dari klan, suku-suku yang ikut mengambil peran dalam menentukan jumlah diyat yang dibebankan oleh keluarga korban. Apabila suku tersebut adalah suku terhormat maka akan terjadi egoistis di dalam pengambilan keputusan besaran diyat. Menurutnya, besaran yang tinggi dan tidak terbatas dari denda pembayaran diyat bukanlah diyat melainkan takwid yakni kompensasi.

Pendekatan diplomasi dalam penanganan diyat di Arab Saudi yakni pendekatan spiritual dan kultural melalui alasan religius dan unsur ibadah. Hal ini dilakukan oleh Lajnah Aflah Lil-islahil Bayin dan perwakilan PWNI \& BHI dalam pendampingan WNI dalam menyelesaikan qishas dan diyat di Arab Saudi. Sebagaimana contoh kasus Satinah yang dilakukan oleh Kementerian Luar Negeri berhasil menurunkan besaran diyat dari 15 Juta riyal menjadi 7 juta riyal.

Pada dasarnya diyat sebenarnya bukan menjadi tujuan utama dari keluarga korban, melainkan hanya pengganti rasa sedih. Pada proses negosiasi dan diplomasi telah dilakukan, mekanisme yang dilakukan jika dimaafkan oleh keluarga korban maka dibuat pernyataan pemaafan dari pihak keluarga korban melalui Lajnah Aflah dan di dalamnya tertera kisaran jumlah diyat yang harus ditunaikan oleh terdakwa. Setelah proses tersebut, kemudian dokumen yang berisi pemaafan dan kisaran biaya diyat yang harus ditunaikan diajukan ke pengadilan syariah sebagai tempat terakhir penentu vonis hukuman.

Perlu dipahami bersama bahwa negosiasi diyat yang dilakukan antara terdakwa (WNI yang terkena tindak pidana) yang didampingi oleh Dit. PWNI \& BHI Kemlu kepada pihak keluarga korban, tidak menghilangkan proses hukum konstitusi Arab Saudi. Tetapi masih diberlakukan hukuman pidana bagi terdakwa untuk mempertanggungjawabkan pelanggaran hukum yang dilakukan.

Dr. Lalu Muhammad Iqbal mengemukakan terdapat 228 WNI terancam hukuman mati di seluruh dunia dan 38 orang berada di Arab Saudi. ${ }^{18}$ Qishas menjadi salah satu hukuman yang mengancam WNI di Arab Saudi. Isu hukum pancung menjadi isu hangat pemerintah Indonesia dan menimbulkan respon dari berbagai pihak termasuk masyarakat Indonesia. Sebagai sebuah hukum yang berlandaskan Islam, hukum pancung memiliki mekanisme tersendiri yakni jika dimaafkan maka harus

17 Ahmad Masbukin merupakan Diplomat RI pendamping Hukum TKI yang terkena tindak pidana, PWNI Kementerian Luar Negeri RI. Wawancara dilakukan pada Senin, 12 Oktober 2015 Direktorat PWNI Kementerian Luar Negeri RI.

18 Pernyataan Dr. Lalu Muhammad Iqbal dilangsir dalam epaper_republika pada tanggal 16 April 2015 
membayar diyat. Sayid Sabiq mendefisikan diyat adalah sejumlah harta yang dibebankan kepada pelaku karena terjadinya tindak pidana (pembunuhan atau penganiayaan) dan diberikan kepada korban atau walinya. ${ }^{19}$

Tradisi legal Islam menempatkan diyat sebagai sebuah metode kompensasi (Blood Money) apabila pelaku dimaafkan oleh keluarga korban dan hal tersebut mengandung nilai keberanian dari pelaku serta pemberian maaf dari keluarga korban. ${ }^{20}$ Kemunculan diyat pada awalnya adalah metode resolusi konflik dalam sistem ekonomi Arab pra-Islam dimana terjadi barter dengan mengorbankan banyak darah untuk satu korban pada sebuah klan sehingga memunculkan praktik bisnis atau balas dendam ketika terjadi pembunuhan. Kemunculan diyat adalah sebuah problem solver yang dibawa Islam untuk menyelesaikan permasalahan hilangnya nyawa korban melalui sistem negosiasi.

Praktik di lapangan, diyat menjadi sebuah polemik bagi pemerintah Indonesia. Dalam hal ini Kementerian Luar Negeri sebagai perwakilan pemerintah untuk menangani masalah WNI, berupaya melakukan negosiasi kepada keluarga korban untuk menentukan ukuran denda diyat. Meskipun kadar pembayaran diyat telah tertera dalam syariah Islam dan telah tertulis dalam Dekrit Raja namun pada praktiknya denda pembayaran diyat dapat tinggi dan melebihi batas ukuran syar'i yang ditetapkan. Teguh Hendro Cahyono, Direktur Mediasi dan Advokasi BNP2TKI mengatakan bahwa uang denda diyat yang sangat tinggi dapat dialokasikan untuk kemaslahatan umat dan pengentasan kemiskinan. Teguh pula menyampaikan banyaknya kasus yang terjadi di Arab Saudi disebabkan oleh banyak faktor, diantaranya: masalah adat budaya, pengetahuan yang minim serta psikologi pribadi TKI yang tidak stabil. Ditemukan masalah pribadi TKI sehingga memicu permasalahan yang berakibat pada pembunuhan keji. Selain itu, usia yang belum matang yakni 17 dan 18 tahun juga menjadi salah satu pemicu dari tindak kriminalitas yang dilakukan TKI. ${ }^{21}$

Jika merujuk pada syariah Islam khususnya pada pendapat Imam Abu Yusuf, Imam Muhammad ibn Hasan, dan Imam Ahmad bin Hanbal menjelaskan jenis diyat ada enam macam:

1. Unta $=100$ ekor

2. Emas $=1000$ dinar

3. Perak $=10.000$ dirham

4. $\quad$ Sapi $=200$ ekor

5. $\quad$ Kambing $=1000$ ekor

6. $\quad$ Pakaian $=200$ setel pakaian. ${ }^{22}$

Pembayaran di era modern, pembayaran diyat tidak lagi menggunakan pembayaran dengan jenis di atas melainkan lebih kepada kurs mata uang Arab Saudi. Kurs Saudi terhadap Indonesia +/- Rp.3.700,-. Jika mengacu kisaran diyat syar'i berdasarkan Dektrit Raja yakni hanya 400 ribu riyal bagi korban laki-laki dan setengahnya yakni 200 ribu riyal bagi perempuan.

Polemik yang terjadi di Indonesia terkait masalah diyat adalah siapa yang bertanggungjawab terhadap pembayaran diyat karena dirasa denda diyat yang ditanggung WNI yang bermasalah cukup besar. Seperti contoh kasus yang menimpa

\footnotetext{
${ }^{19}$ Ahmad Wardi Muslich. Hukum Pidana Islam. (Jakarta: Sinar Grafika, 2005) Hlm. 166

20 S.Z. Ismail / Arab Law Quarterly 26 (2012) 362

${ }^{21}$ Pemaparan disampaikan dalam FGD dengan tema "Mengurai Permasalahan Kasus Diyat

di Tenaga Kerja Indonesia di Timur Tengah" yang diselenggarakan oleh iMERC UI pada 29 Oktober 2015 di Gedung IASTH Lantai 3 Kampus UI Salemba.

${ }^{22}$ HR. Abu Dawud dengan sanad 'Amr ibn Syu'aib dari ayahnya dari kakeknya, dalam pidato Umar bin Khatab.
} 
Satinah yang harus menanggung denda diyat sebesar 7 juta riyal, sama dengan 21 milyar dan Darsem senilai 2 juta riyal atau 4,6 milyar rupiah. Munculnya opini yang mengkritisi kebijakan pemerintah terhadap perlindungan WNI yang dianggap lemah menimbulkan persepsi bahwa berapapun denda besaran diyat maka pemerintah harus ikut andil dalam pembayaran. Dalam hal ini opini yang terbangun adalah pemerintah atas nama Kementerian Luar Negeri wajib ikut serta dalam menyelesaikan pembayaran diyat bagi WNI yang melakukan tindakan pembunuhan namun dimaafkan oleh keluarga korban.

\section{Persepsi Publik mengenai Kasus Diyat}

Penggantian hukuman mati menjadi pembayaran diyat di Arab Saudi harus melalui proses pengadilan. Jumlah tebusan sangat bergantung pada pertimbangan hakim setelah berunding dengan keluarga korban. Secara umum, hakim akan mempertimbangkan beberapa hal antara lain, orang yang terbukti secara sah menurut hukum membunuh orang mukmin, dalam kategori sengaja, tidak disengaja, atau mirip disengaja. Jika keluarga korban merelakan diyat tersebut, terhukum dan keluarganya tidak wajib membayar diyat tersebut. Berkenaan dengan pembayaran diyat, Indonesia secara khusus tidak memiliki badan khusus yang mengkoordinasikan pengumpulan dan pembayaran diyat untuk WNI yang terkena kasus pelanggaran hukum di luar negeri. Hal ini terlihat pada beberapa kasus WNI yang harus membayar diyat di Arab Saudi. Dengan demikian, Indonesia hanya akan membayar sesuai dengan batas adat istiadat di negara setempat. Contohnya, jika WNI melakukan pelanggaran hukum di Arab Saudi dan wajib membayar diyat, maka pemerintah hanya akan membantu pembayaran senilai 200 ekor unta, atau setara dengan 400 ribu riyal. Namun jika WNI tersebut adalah korban atau tidak bersalah maka akan dilakukan perjuangan maksimal seperti melakukan pembelaan, negosiasi dan penggalangan dana.

Dalam beberapa tahun terakhir, tuntutan besaran jumlah diyat yang diminta oleh keluarga korban dalam suatu kasus pembunuhan yang dilakukan oleh WNI yang bekerja di Arab Saudi terus meningkat secara tajam. Uang diyat pada kasus Darsem sebesar 2 juta riyal. Tetapi dalam perkembangan terakhir, permintaan diyat sudah mencapai 7 juta riyal pada kasus Satinah. Melonjaknya permintaan diyat ini sangat dilematis bagi pemerintah Indonesia. Jika dipenuhi maka dikhawatirkan angka uang diyat ini akan terus membengkak, tapi sebaliknya jika tidak dihiraukan, maka nyawa WNI bisa berujung pada kematian.

Teguh Hendro Cahyono, Direktur Media dan Advokasi BNP2TKI, mengungkap bahwa kasus-kasus yang menimpa WNI yang bekerja di luar negeri banyak disebabkan ketidakpuasan para user terhadap kinerja TKI non formal di luar negeri khususnya Arab Saudi. Hal ini disebabkan perekrutan dan seleksi TKI yang akan ke luar negeri tidak sesuai prosedur dan ketentuan yang ada.

Kepala BNP2TKI periode 2007-2013, Jumhur Hidayat menilai bahwa pemerintah telah mengupayakan yang terbaik bagi perlindungan TKI di luar negeri yang salah satunya adalah melalui jalan diplomasi yang memperjuangakan TKI agar dapat dibebaskan dari vonis hukuman mati. Bila dalam perjalanannya terjadi diyat, negara dapat mengupayakan pendanaan pada level tertentu yang besarannya mengacu pada diyat syar'i (diyat minimal). Bilamana ada permintaan diyat yang tinggi, negara dapat membentuk sebuah lembaga ad hoc yang diumumkan dan dipimpin oleh orang yang terpercaya secara moral untuk menerima sumbangan dari dermawan-dermawan. Dengan kata lain, negara telah memfasilitasi dalam kegiatan penggalangan dana. Pendapat ini sejalan dengan yang terjadi pada kasus Joselito Zapanta Warga Negara Filipina. Dalam kasus tersebut Pengadilan Saudi memutuskan hukuman mati kepada Zapanta. Namun demikian, terjadi negoisasi antara pihak Zapanta dengan keluarga korban dan menghasilkan kesepakatan bahwa Zapanta harus membayar uang diyat 5 
juta riyal atau 50 juta peso. Kemudian, Presiden Aquino mengirim utusan untuk bernegoisasi dengan keluarga korban sehingga mendapatkan hasil yang signifikan yaitu penurunan uang diyat dari keluarga korban yang awalnya harus membayar 5 juta riyal menjadi 4 juta riyal atau 45 juta peso dan penundaan eksekusi. Langkah kedua yang dilakukan Pemerintahan Filipina adalah membuat satuan tugas dibawah kendali Wakil Presiden Filipina. Wakil Presiden Filipina Binay mengumpulkan sumbangan dari rakyat Filipina untuk pembayaran uang diyat Zapanta. Kedubes Filipina di Riyadh pun ikut serta membuka rekening untuk pengumpulan dana uang diyat Zapanta. Kesinergian pengumpulan dana antara pemerintah pusat, pemerintah daerah dan rakyat membuahkan hasil dengan terkumpulnya sumbangan dana pembayaran diyat Zapanta sebesar 4 juta peso. Dari kasus tersebut dapat diambil pelajaran bahwa jika proses diplomasi telah dijalankan sebaik-baiknya, maka jalan lainnya negara dapat mengupayakan pembayaran sesuai dengan diyat syar'i. Atau dengan langkah kedua membentuk satuan khusus dipimpin oleh seorang wakil presiden atau menteri koordinator ${ }^{23}$ untuk melakukan penggalangan dana dari masyarakat secara terbuka dan bertanggung jawab.

Wahyu Susilo, Analis Kebijakan Migrant Care mengatakan bahwa persoalan diyat yang menimpa TKI di luar negeri dapat diatasi bila pemerintah meninggalkan gaya advokasi ad hoc dalam berdiplomasi dikarenakan hal ini tidak efektif. Menurutnya, diperlukan kesiapan mitigasi sedari awal bagi pemerintah dalam kasus buruh migran, maka penyelesaian kasus dengan pembayaran diyat dapat diminimalisir. Untuk itu, diperlukan sinergi diplomasi yang sama antara seluruh aparat dan pemerintah.

Kekhawatiran Migrant Care, pada dasarnya telah diantisipasi pemerintah, dalam hal ini Direktorat Perlindungan WNI dan BHI Kemlu. Muhammad Sadri, konsuler KJRI Jeddah periode 2009-2013 yang juga Kasi Repatriasi 2013-2015 Direktorat Perlindungan WNI dan BHI, Direktorat Jenderal Protokol dan Konsuler, Kementerian Luar Negeri, mengungkapkan bahwa negara dalam hal ini pemerintah, telah memberikan bantuan maksimal bahkan lebih. Upaya yang telah dilakukan pemerintah antara lain, memastikan adanya pendampingan hukum bagi WNI yang terancam hukuman mati di setiap tingkatan proses hukum (advokasi) melalui mekanisme Unit Kerja Khusus; menyediakan pengacara retainer di beberapa Perwakilan RI; mengalokasikan anggaran/dana untuk bantuan hukum dan upaya pembebasan lainnya; pendekatan kepada keluarga korban untuk tindak pidana pembunuhan agar mendapatkan pemaafan (khusus Arab Saudi); pendekatan melalui saluran diplomatik, baik yang dilakukan oleh pemerintah pusat maupun Perwakilan RI. Selain itu, upaya-upaya yang dilakukan oleh Presiden RI secara langsung kepada kepala pemerintahan terkait, dan pembentukan Satgas penanganan WNI yang terancam hukuman mati di luar negeri sesuai Keppres No. 17 Tahun 2011.

Sebagai perbandingan, ia menyebutkan bahwa di negara lain, contohnya Pakistan, pemerintah negara tersebut tidak bersedia membantu warganya yang terlibat kasus kriminal yang berujung pada pembayaran diyat, karena pada dasarnya hal ini menjadi pelajaran dan dapat memberi efek jera pada pelaku. Sehingga bagi Pakistan, diyat bukan merupakan kewajiban negara. Namun di Indonesia, negara dalam hal ini Kemlu sebagai otoritas pemerintah yang salah satunya menangani persoalan WNI diluar negeri, justru melakukan pembayaran diyat sebagai wujud perlindungan WNI di luar negeri. Padahal, kewajiban perlindungan warga negara menurut Konvensi Wina 1963 dan customary international law, bahwa kewajiban utama pemerintah sebuah negara terkait perlindungan kepada warga negaranya yang melakukan tindakan kriminal di

23Pendapat Prof. Hikmahanto dalam wawancara 
luar negeri adalah sebatas memberikan bantuan/pendampingan hukum serta memastikan WNI yang bersangkutan memperoleh fair trial (proses pengadilan yang adil). Dengan demikian, segala upaya yang telah dilakukan Pemerintah Indonesia dalam penyelesaian kasus-kasus hukuman mati yang menimpa WNI di luar negeri, termasuk kasus Satinah selama ini telah melampaui apa yang menjadi kewajiban. Karena pada hakekatnya pembayaran diyat adalah masalah pribadi antara ahli waris korban dan keluarga pelaku. Sehingga, berbagai upaya yang telah dilakukan pemerintah Indonesia, dalam hal ini Kemlu diluar rujukan pada Konvensi Wina 1963 dan customary international law tetap dilakukan oleh Kemlu, diantaranya berbagai upaya untuk menurunkan tuntutan besaran diyat dan menggalang dana untuk memenuhi besaran diyat semata-mata merupakan bentuk kepedulian dan keberpihakan Kemlu pada WNI.

\section{KESIMPULAN}

Prof. Hikmahanto Juwana menilai pembayaran diyat yang dilakukan oleh pemerintah RI untuk membantu para TKI yang terkena kasus diyat tidak sesuai prosedur. Karena pendampingan dalam perlindungan hukum yang menjadi kewajiban pemerintah telah dipenuhi oleh kemlu. Hal ini menimbulkan adanya mafia diyat baik dari pihak negara Arab Saudi maupun Indonesia sendiri yang akan mempermainkan besaran diyat hingga melambung tinggi. Untuk itu, solusi yang ditawarkan pakar hukum Universitas Indonesia ini bagi permasalahan diyat yang menimpa TKI adalah dengan menerapkan surat perjanjian (Letter of Agreement) antara pemerintah RI dengan Arab Saudi terkait TKI yang meliputi; jam kerja para TKI, besaran pembayaran upah, perlindungan hukum dan lain sebagainya. Selain itu, perlu adanya early warning system bagi pemerintah Indonesia dalam rangka perlindungan bagi TKI di luar negeri yang ditangani secara khusus oleh Menteri Koordinator, di bawah salah satu kementerian sebagai wujud sinergitas bagi seluruh lembaga yang menangani TKI.

Sejalan dengan Undang Undang Dasar 1945 yang didukung oleh Konvensi Wina 1963, negara pada dasarnya hadir untuk melindungi warganya. Dengan demikian, untuk menyikapi persoalan diyat, diperlukan perbaikan dan tata kelola yang menyeluruh dalam sistem perekrutan TKI ke luar negeri yang efektif dan efisien dari hulu ke hilir secara menyeluruh. Adapun solusi bagi pembayaran diyat, apabila terpaksa harus dilakukan, maka mekanisme yang ditawarkan sebagai solusi ialah dengan menyediakan program asuransi khusus TKI, melalui skema bantuan dari lembaga seperti baitul maal atau CSR khusus masalah TKI yang terkena diyat. Selain itu, diplomasi spiritual kultural yang mana terjalin komunikasi yang baik antara pihak pemerintah Indonesia dengan berbagai pihak yang terlibat di luar negeri juga merupakan kunci yang paling utama, tentunya dengan memahami betul adat dan budaya setempat.

\section{DAFTAR PUSTAKA}

Al-Farsy, Fouad. (2001). Modernity and Tradition The Saudi Equation. United Kingdom: Knight Communications. hlm.53

Amnesty International Publication. Affront to justice: death penalty in Saudi Arabia.2008. London.

Badan Nasional Penempatan Perlindungan Tenaga Kerja Indonesia. (2015).

Data Penempatan dan Perlindungan Tenaga Kerja Indonesia Tahun 2015 (Periode 1 Januari S.D 31 januari) Posisi Cetak Data Tanggal 12 Februari 2015. Jakarta.

Creswell, John W. (2003). Research Design: Qualitative, Quantitative, and Mixed Methods Approaches. Second Edition. Sage Publication Inc. 
Frank E. Vogel (2000). Islamic Law and Legal System: Studies of Saudi Arabia. Leiden: Brill George E. Belch \& Michael A. Belch. (2007). Advertising and Promotion, An Integrated Marketing Communication Perspective. McGraw Hill.

Guevarra, Anna Romina. (2010). Marketing Dreams, Manufacturing Heroes: The TransnationalLabor Brokering of Filipino Workers. New Jersey: Rutgers

University Press.

Human Right Watch.(2007). Exported and Exposed: Abuse Against Sri Lankan Domestic Workers in Saudi Arabia, Kuwait, Lebanon, and The United Arab Emirates.Volume 19, No. 16 (C), November.

Huberman and Miles B. Matthew. (2009). Analisis Data Kualitatif : Buku Sumber Tentang Metode-metode Baru. Jakarta: UI Press.

Ismail, Siti Zubaidah. The Modern Interpretation of the Diyat Formula for the Quantum of Damages: The Case of Homicide and Personal Injuries. *. Arab Law Quarterly 26 (2012) 361-379.

Irianto, Sulistyowati. (2011). Akses Keadilan dan Migrasi Global: Kisah Perempuan IndonesiaPekerja Domestik di Uni Emirat Arab. Jakarta: Yayasan Pustaka Obor Indonesia.

Jazuli, Ahmad. (1999). fiqh jinayah. Jakarta: PT RajaGrafindo persada.

Khawaja A dan Hiranya K. Nath, Workers' Migration and Remittance Bangladesh. Journal of Business Strategies. Volume 27, Number 1. 29 -52.

Meolong, Lexy J. (2007). Metodologi Penelitian Kualitatif. Bandung: PT Remaja Rosdakarya Offset.

Mourkarbel, Nayla. (2009).Sri Lankan Housemaids in Lebanon: A Case of 'SymbolicViolence' and Everyday Forms of Resistance.Amsterdam:Amsterdam University Press.

Muslich, Ahmad Wardi. (2005). Hukum Pidana Islam. Jakarta: Sinar Grafika.

Munajat, Makrus (2004). Dekonstruksi Hukum Pidana Islam. Jogjakarta Logun Pustaka.

Munawarsyah., et.al. Analisis yuridis pengaturan besaran diyat terhadap korban konflik di Aceh. Jurnal Ilmu Hukum Pascasarjana Universitas Syah Kuala. ISSN 2302-0180 Volume 2, No. 2, November 2013.

Neuman, W. L. (2000). Social Research Method: Qualitative and Quantitative Approaches, Fourth edition. Allyn and Bacon, Boston, Massachusetts.

Parthasarathi, Prasannan dan Donald Quataert. Migrant Workers in the Middle East:I ntroduction. International Labor and Working-Class History, No. 79, Spring (2011). 4- 6.

Peiffer, Elizabeth. The Death Penalty in Traditional Islamic Law and as Interpreted inSaudi Arabia and Nigeria, 11 Wm. E Mary J. Women E L. 507 (2005), http://scholarship.law.wm.edu/wmjowl/vol11/iss3/9

Rodriguez, Robyn Magalit. Philippine Migrant Workers Transnationalism in the Middle East. International Labor and Working-Class History, No. 79, Spring (2011). 48 - 61.

Tashakkori and Teddlie. (2010). Mixed Methodology: Mengombinasikan Pendekatan Kualitatif dan Kuantitatif. Yogyakarta: Pustaka Pelajar.

Thiollet, Hellen. Migration as Diplomacy Labor Migrants, Refugees, and Arab Regional Politicsin The Oil-Rich Countries.International Labor and Working-Class History, No. 79, Spring (2011) 103 - 121.

Website :

http:/ /news.okezone.com/read/2014/10/12/337/1051244/selama-sby-presiden-tigaburuh-migran-dihukum-mati (diakses pada 1 Agustus 2015)

http://www.cnnindonesia.com/internasional/20150205160919-120-29941/belasanwni-terancam-hukuman-mati-di-arab-saudi/ (diakses pada 1 Agustus 2015) 
http://www.kemlu.go.id/Pages/SpeechTranscriptionDisplay.aspx?Name1=Pidato\& Name2=Menteri\&IDP=818\&l=id (diakses pada 1 Agustus 2015)

http://www.republika.co.id/berita/internasional/global/12/03/20/m160dl-rajaarab-saudi-pun-tak-bisa-cegah-pemancungan (diakses pada 1 Agustus 2015)

http://www.tempo.co/read/news/2014/03/29/173566265/Pembayaran-Diyat-

Dianggap-Contoh-yang-Buruk (diakses pada 1 Agustus 2015)

http://search.proquest.com/docview/1699731232?accountid=17242 (diakses pada 14 November 2015)

http://search.proquest.com/docview/463979639?accountid=17242 (diakses pada 14 November 2015)

http://www.mongabay.com/history/Saudi_Arabia/Saudi_arabia-the_ulama.html (diakses pada 19 Oktober 2015)

https://www.saudiembassy.net/about/country-

information/government/legal_and_judicial_structure.aspx (diakses pada 23 November 2015). 
Diplomasi Spiritual Kultural Dalam Pencegahan...

DOI: https://doi.org/10.55252/annawawi.v1i2.13 